\title{
Konflik Kawasan Hutan Barambang Katute Kabupaten Sinjai (1994-2012)
}

\author{
Nurlinda ${ }^{1}$, M. Rasyid Ridha ${ }^{2}$, Amirullah ${ }^{3}$ \\ Prodi Pendidikan Sejarah Fakultas Ilmu Sosial Universitas Negeri Makassar \\ Email: linbahar09@gmail.com, rasyidridha@unm.ac.id, amirullah8505@unm.ac.id
}

\begin{abstract}
Abstrak
Penelitian ini berupaya menjelaskan tentang latar belakang terjadinya konflik kawasan hutan di Barambang dan Bonto Katute mulai dari sejak pengukuran dan penetapan tapal batas tahun 19941995, pelaksanaan program GN-RHL tahun 2005, hingga eksplorasi tambang tahun 2010 yang berdampak pada kehidupan masyarakat setempat. Terjadinya konflik tersebut dilatar belakangi oleh adanya penetapan Kawasan Hutan Lindung Apparang pada tahun 1982 yang menjadi dasar dilakukannya pengukuran dan penetapan tapal batas wilayah kelola masyarakat dengan kawasan hutan pada tahun 1994-1995 yang memicu aksi protes dari masyarakat, pelaksanaan program GNRHL Disbunhut Kabupaten Sinjai tahun 2005-2008 yang menyebabkan terjadinya sengketa tanah, dan pada tahun 2010 dikeluarkan perpanjangan IUP kepada PT Galena Sumber Energi dan menuai aksi penolakan yang menjadi puncak perlawanan dari masyarakat setempat, hal ini menimbulkan dampak terhadap perekonomian, kehidupan sosial dan budaya masyarakat setempat. Penelitian ini adalah penelitian dengan pendekatan penelitian historis (Historical Research), yang terdiri atas beberapa tahapan yakni: (1) Heuristik, dengan mengumpulkan data mengenai Konflik Kawasan Hutan Barambang Katute Kabupaten Sinjai dengan cara wawancara dengan Ismail, Ali Hasan, Hasibe, Rudi, dan Muh. Masri selaku pelaku dan saksi serta mengumpulkan arsip Putusan Pengadilan Negeri Sinjai, arsip Kantor Desa Bonto Katute dan dokumen lainnya. (2) Kritik atau proses verifikasi keaslian sumber sejarah. (3) Interpretasi atau penafsiran sumber sejarah, dan (4) Historiografi, yakni tahap penulisan sejarah.
\end{abstract}

Kata Kunci : Konflik, Hutan, Bonto Katute

\begin{abstract}
This paper seeks to explain the background of the conflict between forest areas in Barambang and Bonto Katute starting from the measurement and determination of the 1994-1995 boundary, the implementation of the 2005 GN-RHL program, to mining exploration in 2010 that affected the lives of local communities. The occurrence of the conflict was motivated by the establishment of the Apparang Protected Forest Area in 1982 which was the basis for measuring and defining the boundaries of community management areas with forest areas in 1994-1995 which triggered protests from the community, implementation of the Disbunhut GN-RHL program in Sinjai Regency in 2005-2008 which caused land disputes, and in 2010 an IUP extension was extended to PT Galena Sumber Energi and reaped a rejection action which became the peak of resistance from the local community, this has an impact on the economy, social life and culture of the local community. This research is a research with historical research approach, which consists of several stages, namely: (1) Heuristics, by collecting data on the Conflict of the Barambang Katute Forest Area in Sinjai Regency by interviewing Ismail, Ali Hasan, Hasibe, Rudi, and Muh. Masri as the perpetrator and witness and collecting archives of the Sinjai District Court Decision, archives of the Bonto Katute Village Office and other documents. (2) Criticism or the process of verifying the authenticity of historical sources. (3) Interpretation or interpretation of historical sources, and (4) Historiography, namely the stage of historical writing.
\end{abstract}

\section{Keywords : Conflict, Forest, Bonto Katute}




\section{A. Pendahuluan}

Pemerintah berperan membagi kawasan hutan agar tujuan dari pengelolaan hutan dapat tercapai. Berdasarkan status penguasaannya, hutan dapat dibedakan atas hutan negara dan hutan hak. Hutan negara adalah hutan yang berada pada tanah yang tidak dibebani hak atas tanah. Sedangkan hutan hak adalah hutan yang berada pada tanah yang dibebani hak atas tanah (Undang-undang RI No. 41 Tahun 1999 , t.thn.). Adapun wilayah masyarakat hukum adat yang berupa hutan diklarifikasikan sebagai hutan negara (Pasal 1, butir 6). Dengan kata lain hutan negara dapat berupa hutan adat (Pasal 5, butir 2) sepanjang menurut kenyataan masyarakat hukum adat yang bersangkutan masih ada dan diakui keberadaannya (Pasal 5, butir 3) dan apabila dalam perkembangannya masyarakat hukum adat yang bersangkutan tidak ada lagi, maka hak pengelolaan hutan adat kembali kepada pemerintah (Pasal 5, butir 4). (Undang-undang RI No. 41 Tahun 1999 , t.thn.)

Hutan hak yang berada pada tanah yang dibebani hak milik lazim disebut hutan rakyat (Rahmadi, 2015). Hutan ini kebanyakan berada di atas tanah adat atau tanah milik yang umumnya dikelola dan dibangun oleh masyarakat setempat. Meskipun banyak di antara tanah-tanah tersebut masuk dalam kawasan hutan negara atau tanah negara.

Kabupaten Sinjai merupakan salah satu kabupaten yang berada di wilayah Provinsi Sulawesi Selatan yang memiliki kawasan hutan yang cukup luas. Tercatat pada tahun 2005 luas kawasan hutan dirinci per kecamatan dan kelurahan/desa berdasarkan tata guna hutan Kab. Sinjai yaitu jumlah hutan lindung sebanyak 11.749 ha dan hutan produksi sebanyak 7.340 ha (BPS , 2006). Besarnya luas kawasan hutan tersebut tidak jarang mengundang konflik yang melibatkan masyarakat setempat dengan pemerintah daerah khususnya pihak kehutanan. Salah satunya adalah konflik yang terjadi di wilayah Barambang dan Bonto Katute Kecamatan Sinjai
Borong yang bukan hanya sekedar mempersoalkan penetapan kawasan hutan lindung tapi konflik tersebut menjamur hingga masalah penolakan eksplorasi tambang.

Beberapa kajian yang relevan dengan penelitian ini yaitu sebuah karya skripsi dari A. Hamzah Kurniawan yang berjudul "Persistensi dan Resistensi Masyarakat Terhadap Eksistensi Pertambangan Emas di Desa Bonto Katute Kabupaten Sinjai” yang membahas mengenai faktor dan bentuk persistensi dan resistensi masyarakat Desa Bonto Katute terhadap eksistensi penambangan emas yang sudah memasuki tahap eksplorasi.

Kedua, skripsi yang berjudul "Gerakan Petani di Kab. Bulukumba (1994-2003) karya Nirwana. Ketiga, sebuah skripsi karya Albar yang berjudul "Komunitas Adat Cerekang di Luwu Utara (1964-2006)” yang membahas tentang Komunitas Adat Cerekang yang masih eksis menjaga dan melestarikan hutan adat dan sungai serta nilai-nilai luhur dan budaya adat istiadat setempat.

Sejak masuknya gerombolan DI/TII antara tahun 1951-1952 di wilayah adat Barambang Kaute membuat keberadaan masyarakat adat tersebut mulai melemah. Selanjutnya, berlakunya sistem pemerintahan desa pada tahun 1962 telah mengganti sistem pemerintahan adat yang diterapkan sebelumnya di wilayah adat mereka. Kemudian Desa Barambang yang dulunya satu wilayah dengan Desa Bonto Katute akhirnya dimekarkan pada tahun 1989.

Awal kemunculan konflik dimulai setelah adanya pemekaran Desa Barambang menjadi satu yaitu Desa Bonto Katute. Status kawasan hutan lindung yang telah ditetapkan pada tahun 1982 menjadi dasar dilakukan program kehutanan. Pada tahun 1994, kehutanan melakukan pengukuran di wilayah Desa Barambang dan Bonto Katute. Pengukuran tersebut bertujuan untuk penetapan tapal batas antara wilayah kelola masyarakat dengan kawasan hutan lindung. Namun dalam 
tahap pelaksanaannya memicu aksi protes dari masyarakat karena mereka menilai tidak ada sosialisasi sebelumnya

Tahun 2005 Dinas Kehutanan Kabupaten Sinjai kembali mengeluarkan kebijakan rehabilitasi hutan dan lahan yang dikenal dengan nama Gerakan NasionalRehabilitasi Hutan dan Lahan (GN-RHL). Salah satu tempat yang dicanangkan oleh Dinas Kehutanan Kabupaten Sinjai adalah wilayah Desa Bonto Katute sebagai tempat penerapan program GN-HRL. Program tersebut ditentang oleh masyarakat setempat dan melarang menanami lahan mereka. Sehingga pada tahun 2008, sebanyak 11 orang dilaporkan oleh pihak kehutanan telah melakukan perambahan kawasan hutan lindung

Belum selesai kasus perambahan hutan yang dituduhkan Dinas Kehutanan Kabupaten Sinjai, pada tahun 2010 dikeluarkan izin eksplorasi tambang di Desa Bonto Katute oleh Bupati Sinjai kepada PT. Galena Sumber Energi. Hal ini sontak menjadi puncak perlawanan masyarakat Desa Bonto Katute yang dibantu oleh berbagai Lembaga Swadaya Masyarakat (LSM) dan beberapa organisasi mahasiswa. Mereka yang tergabung dalam front penolakan tambang Barambang Katute yang dinamakan Gerakan Rakyat Tolak Tambang Bonto Katute (GERTAK) berupaya menolak keberadaan eksplorasi tambang tersebut. Konflik tersebut telah menimbulkan dampak yang sangat berpengaruh terhadap kehidupan masyarakat setempat.

\section{B. Metode Penelitian}

1. Heuristik

Heuristik artinya mencari dan mengumpulkan sumber-sumber sejarah mengenai topik yang akan di kaji, yakni "Konflik Kawasan Hutan Barambang Katute Kabupaten Sinjai (1994-2012) penulis menempuh dua cara yaitu penelitian pustaka dan penelitian lapangan. Adapun sumber pustaka yang digunakan adalah buku Hukum Lingkungan di Indonesia karya Prof. Dr. Takdir Rahmadi,
S.H., LLM. Hukum Sumber Daya Alam karya Marcel Slamet, dan salah satu buku karya Noer Fauzi Rahman yang berjudul Petani dan Penguasa Dinamika Perjalanan Politik Agraria, Arsip Pengadilan Negeri Sinjai, Dokumen-dokumen pribadi narasumber, arsip Kantor Desa Bonto Katute. Dalam mengumpulkan sumbersumber menggunakan teknik penelitian lapangan dilakukan dengan observasi dan wawancara dengan Ismail, Ali Hasan, Hasibe, Rudi dan Muh. Masri.

\section{Kritik Sumber}

Kritik sumber merupakan bagian penafsiran dan pengkajian sumber. Proses yang menilai apakah sumber itu memiliki kredibilitas (kebiasaan untuk dipercaya) atau tidak. (Priyadi, 2012)

\section{Interpretasi}

Pada tahap ketiga peneliti harus menafsirkan data-data yang telah diperoleh. Proses menafsirkan memerlukan ketelitian dari seorang penulis untuk memilah data mana yang penting untuk tema penelitian dan data mana yang tidak berkaitan dengan penelitian.

\section{Historiografi}

Dalam kaitannya dengan historiografi, yaitu proses penulisan sejarah banyak aspek yang terkait di dalamnya. Menurut Hexter, proses pengumpulan bukti bukti sejarah, pengeditan sumber sejarah, penggunaan pemikiran dan imajinasi sejarah, dan sebagainya merupakan suatu proses yang tidak dapat dipisahkan dari historiografi. (Haryono, 1995)

\section{Tinjauan Penelitian}

1. Sejarah Masyarakat Adat Barambang Katute

Sejarah keberadaan orang pertama di Barambang Katute mula-mula berada di tanah yang disebut Lempangan Ritanah Toa atau tanah tua. Menurut sejarah yang tertuang dalam lontara warisan mereka secara turun temurun, di tempat tersebutlah pertama kali muncul seorang To Manurung yang berjenis kelamin laki-laki. Kemudian di tempat lain yang dikenal dengan nama Pabbattu muncul orang kedua berjenis 
kelamin perempuan. Keduanya lalu menikah dan melahirkan anak yang dikenal sebagai ana' dinru laheng yang memiliki makna bahwa anak tersebut yang dilahirkan dengan kembar, satu laki-laki dan satu perempuan. Salah satu anak yang berjenis kelamin laki-laki meninggalkan Lempangan Ritana Toa, sementara saudaranya yang perempuan tetap tinggal di Lempangan Ritana Toa tersebut. anak perempuan tersebutlah yang kemudian melahirkan empat orang anak yang dikenal dengan istilah ana' eppa.

Ana' eppa tersebutlah yang dilantik menjadi pemangku adat di tiga kampung yakni Kampung Katute, Kampung Bihulo, dan Kampung Gantarang. Anak pertama dilantik sebagai Ada' Tungka ri Katute, anak kedua sebagai SanroTungka ri Bihulo, anak ketiga sebagai Karaeng Tungka ri Gantarang. Ketiga pemangku adat tersebut kemudian dikenal dengan istilah ada' tallua. Mereka kemudian dilantik oleh si anak bungsu, sementara si bungsu atau anak ke empat menjadi Uwwa yang diartikan sebagai penasihat dari ketiga saudaranya yang menjalankan sistem pemerintahan selaku pemerintah adat.

Mereka membangun sebuah rumah pertama di Lengkese yang dikenal dengan istilah Mabbola Syibatu ri Lengkese. Di rumah tersebutlah mula-mula dikenal adanya Paruru, Halasuji, Lamming, Campaniga. Kemudian mereka membuat rumah dan berdiam di Bontolasuna dan disinilah cikal bakal diangkatnya seorang pemimpin adat yang disebut Puang Barambang.

Sekitar abad 5 M, orang pertama yang menjadi Pa'Barambang adalah Barambang Camu yang menempati rumah di Bontolasuna Desa Barambang. Rumah tersebut merupakan rumah adat bagi Masyarakat Adat Barambang Katute. Di sinilah awal mula perkembangan Masyarakat Adat Barambang Katute sampai menyebar ke Bonto Katute, Bolalangiri, Coddong, Bihulo, Ambi dan Kampung Balang. Di setiap kampung di kepalai seorang kepala kampung yang merupakan perwakilan dari Puang Barambang yang berkuasa pada saat itu. (AMAN Sinjai, t.thn.)

2. Eksistensi Masyarakat Adat Barambang Katute Pasca Terbetuknya NKRI

Setelah kemerdekaan Indonesia diproklamasikan pada tanggal 17 Agustus 1945, bangsa Indonesia mulai melakukan penataan terhadap negaranya. Namun kemerdekaan tersebut belum mampu menyatukan seluruh bangsa Indonesia. Hal itu terlihat dari beberapa kelompokkelompok masyarakat yang melakukan pemberontakan. Salah satunya yaitu organisasi pemberontakan DI/TII yang ingin mendirikan negara Islam.

DI/TII tersebar di beberapa wilayah Indonesia salah satunya di Sulawesi Selatan. Kedatangan gerombolan tersebut menjadi awal dari melemahnya keberadaan Mayarakat Adat Barmbang Katute (Rudi, 2018).

Barambang Caureng melakukan perlawanan kepada gerombolan DI/TII akan tetapi dia dikalahkan. Setelah Barambang Caureng dibunuh, gerombolan DI/TII kemudian membakar rumah adat Barambang Katute yaitu Bola Loppoe yang di dalamnya terdapat benda-benda pusaka Masyarakat Adat Barambang Katute. Pasca pembakaran tersebut tidak ada satu pun benda pusaka yang tersisa. Kemudian masyarakat adat Barambang Katute menjadikan salah satu rumah warga sebagai pengganti Bola Loppoe yang telah dibakar. (Mappa, 2018)

Setelah meninggal Pa'Barambang Caureng antara tahun 1954-1956 berubahlah nama pemerintahan yaitu $A d e^{\prime}$ yang sistem pemerintahannya sama dengan Pa'Barambang yang dipimpin oleh Bacora Masse yang menjabat sampai tahun 1958. Pada tahun 1962, terbentuklah desa dan Barambang diabadikan menjadi nama desa. Berdasarkan hasil pemilu terpilihlah Patong sebagai Kepala Desa Barambang. Pada tahun 1989 Desa Barambang dimekarkan menjadi satu desa yaitu Bonto Katute (desa persiapan Bonto Katute) dan membentuk 
empat dusun yaitu Maroanging, Gori-gori, Coddong, Bolalangiri dengan mengangkat Masse. P sebagai kepala desa persiapan. Pada tahun 1992 Bonto Katute diresmikan menjadi satu desa di Desa Kaloling Sinjai Timur. (Kantor Desa Bonto Katute, t.thn.)

\section{Pembahasan}

\section{Latar Belakang Konflik}

Pada tanggal 12 Oktober 1982 telah dikeluarkan SK Menteri Pertanian dengan Nomor : 760/kpts/um/10/82 Tentang Penunjukan Kawasan Hutan menjadi Kawasan Hutan Lindung di wilayah Kecamatan Sinjai Borong, Sinjai Barat dan Sinjai Tengah (Pengadilan Negeri Sinjai Kelas II, t.thn.). Tak berselang lama dari adanya penetapan ini kemudian diterapkan program reboisasi di wilayah Desa Barambang Kecamatan Sinjai Borong Kabupaten Sinjai.

Penetapan Kawasan Hutan Apparang di Sinjai Borong menuai konflik karena dinilai tidak ada sosialisasi sebelumnya. Setelah pemekaran Desa Barambang menjadi Desa Bonto Katute pada tahun 1989, kembali pihak kehutanan mengadakan pengukuran dan penetapan tapal batas wilayah kawasan hutan lindung dengan wilayah kelola masyarakat pada tahun 1994-1995. Masyarakat melakukan aksi protes karena mereka dinilai mengambil keputusan secara sepihak. Padahal masyarakat telah mendiami wilayah tersebut sejak dahulu dan mengelola lahan mereka secara turun temurun bukan hanya itu mereka juga telah menganggap ada hutan larangan/hutan adat yang tidak boleh dikelola selain untuk mengambil bahan pembuatan rumah atau rotan. Sekalipun pengakuan terhadap keberadaan masyarakat adatnya tidak diakui lagi oleh pemerintah daerah, mereka tetap meyakini bahwa mereka adalah suatu kesatuan masyarakat adat yakni Masyarakat Adat Barambang Katute.

Setelah resmi ditetapkan sebagai kawasan hutan lindung, Dinas Kehutanan Kabupaten Sinjai kembali menerapkan program GN-RHL di Desa Bonto Katute.
Selama pelaksanaan program ini, beberapa masyarakat dituduh telah melakukan perambahan dan perusakan hutan. Mereka menolak telah melakukan seperti yang dituduhkan karena mereka menilai bahwa lahan yang mereka kelola telah dimiliki secara turun temurun. Kasus tersebut akhirnya diselesaikan lewat jalur hukum hingga tingkat kasasi.

Belum selesai persoalan tuduhan perambahan hutan, masyarakat kembali diperhadapkan dengan adanya izin eksplorasi tambang dari PT. Galena Sumber Energi di Desa Bonto Katute. Keberadaan eksplorasi tambang tersebut menuai kontroversi, meskipun tidak semua masyarakat menolak keberadaan tambang tersebut. Masyarakat yang mendukung ingin membuktikan kebenaran adanya emas di kampung mereka dan mereka menilai dengan adanya tambang tersebut dapat mengangkat desa mereka dan bisa memperkenalkan ke wilayah luar selain itu mereka tidak khawatir karena mereka akan diberikan ganti rugi. Namun dari masyarakat yang menolak menilai bahwa yang adanya tambang tidak akan memberikan kesejahteraan kepada masyarakat justru akan membuat mereka sengsara. Meskipun masih dalam tahap eksplorasi, tambang tersebut telah menuai penolakan oleh masyarakat yang dibantu oleh LSM dan organisasi mahasiswa.

\section{Dinamika Konflik}

a. Pengukuran dan Penetapan Tapal Batas

Sejak Desa Barambang dimekarkan menjadi satu desa yakni Desa Bonto Katute pada tahun 1989, pihak kehutanan melakukan pengukuran dan penetapan pal batas kawasan hutan produksi tetap di Desa Barambang dan Desa Bonto Katute. Penetapan tapal batas tersebut bertujuan untuk memisahkan wilayah kawasan hutan lindung dengan wilayah kelola masyarakat. Selain itu, tujuan dari pemisahan ini adalah untuk kepentingan bersama. Menurut pengakuan dari Kepala Resor Polisi Hutan pada saat itu, Ali Hasan bahwa wilayah tersebut sudah ditetapkan sebagai kawasan 
hutan lindung sejak tahun 1982. (Hasan, 2018)

Pengukuran tersebut dimulai pada tanggal 4 November 1994 di Desa Barambang yang berlangsung selama beberapa hari dengan menetapkan tapal batas terhadap wilayah kelola masyarakat dengan wilayah kawasan hutan lindung. Dalam tahap pelaksanaannya warga merasa curiga karena tidak ada sosialisasi sebelum adanya pengukuran tersebut sehingga membuat warga bertanya-tanya apa tujuan mereka sesungguhnya. Namun, alasan yang disampaikan oleh pihak pengukur bahwa tujuan dari pengukuran itu adalah untuk pembuatan jalan.

Ismail yang merupakan salah seorang dari kepala dusun yang ada di Desa Barambang yaitu Dusun Batu Massompe mengaku bahwa dirinya tidak tahu menahu persoalan adanya pengukuran di wilayah mereka. Bahkan dirinya sebagai kepala dusun sama sekali tidak pernah mendapatkan pemberitahuan dari kepala desa. Beliau baru mengetahui setelah mendapatkan laporan dari beberapa warga. (Ismail, 2018)

Pada tanggal 6 November 1994 pengukuran sudah sampai di Desa Bonto Katute. Kedatangan pengukur di Desa Bonto Katute juga disambut kegelisahan oleh masyarakat terutama yang berada di Dusun Bolalangiri. (Ismail, 2018)

Pada tahun 1995 beberapa orang dilaporkan dengan tuduhan melakukan tindak pidana menghasut dan memfitnah kekuasaan umum serta penipuan. Mereka adalah Ismail yang sudah menjabat sebagai Kepala Dusun Batu Massompe selama 5 tahun, Rustam Hamka yang juga merupakan seorang mahasiswa di salah satu perguruan tinggi di Makassar, dan Tenteng seorang petani dari Dusun Balang Desa Barambang.

Tepat pada tanggal 11 September 1995, Ismail dan Tenteng ditangkap dan dibawa ke Kantor Polisi Kabupaten Sinjai berdasarkan Surat Perintah Penangkapan No. A.5/06/IX/1995/SERSE tanggal 7 September 1995 dan No. Pol:
A.5/06/IX/1995/SERSE tanggal 15 September 1995 dengan tuduhan melakukan tindak pidana menghasut dan memfitnah kekuasaan umum serta penipuan. Seminggu setelahnya Rustam Hamka dijemput di lokasi KKN yakni di Kabupaten Barru dengan tuduhan yang sama. Setelah diperiksa di Kantor Polisi, Tentang akhirnya dipulangkan dikarenakan terbukti tidak bersalah.

Sedangkan pada tahun yang sama, dikeluarkan SK penetapan hasil pengukuran yang telah ditetapkan batasbatas wilayah kelola masyarakat dengan wilayah kawasan hutan lindung. Keputusan tersebut berdasarkan SK Menteri Kehutanan Nomor 384/Kpts II/1995 tentang Penetapan Kelompok Hutan Aparang II yang terletak di Kabupaten Sinjai, Provinsi Daerah Tingkat I Sulawesi Selatan, seluas 112, 8 Hektar, Sebagai Kawasan Hutan Dengan Fungsi Hutan Produksi Tetap tertanggal 25 Juli 1995. (Balai Pemantapan Kawasan Hutan Wilayah VII Makassar, t.thn.)

\section{b. Pelaksanaan Program GN-RHL}

Pada tahun 2005 Disbunhut mencanangkan Bonto Katute sebagai tempat pelaksanaan Program Gerakan Nasional-Rehabilitasi Hutan dan Lahan (GN-RHL). Program tersebut merupakan salah satu upaya pemerintah untuk mengatasi kerusakan hutan dan lahan yang terjadi di Indonesia. Program ini melibatkan banyak pihak seperti pemerintah daerah, LSM, instansi terkait, dan masyarakat. Berdasarkan data pada tahun 2006 luas lahan yang ditanami sekitar 87 Ha yang terdiri dari tanaman pohon pinus, pohon mahoni, gamelina, dan kayu manis. Penanaman tersebut menelan anggaran senilai Rp. 167 juta yang berasal dari APBN. (Hasibe, 2018)

Pelaksanaan program tersebut memicu konflik antara masyarakat dan Disbunhut yang berujung pada sengketa lahan. Berdasarkan keterangan dari Kepala Desa yaitu Muh. Masri yang juga bertugas sebagai polisi hutan pada saat pelaksanaan program GN-RHL. (Masri, 2018) 
Polisi hutan yakni Sommeng dan Yusuf sebagai mandor hutan yang ditugaskan untuk memantau lokasi pelaksanaan program GN-RHL tersebut menemukan pohon pinus yang dicabut dan melaporkan kepada dinas kehutanan. Pada tanggal 05 Januari 2009 Kepala Dinas Perkebunan dan Kehutanan Kabupaten Sinjai, Ir. H. Achmad Rasyid melaporkan beberapa masyarakat dengan tuduhan melakukan perusakan hutan lindung di Dusun Bolalangiri, Desa Bonto Katute Kecamatan Sinjai Borong Kabupaten Sinjai. Berdasarkan laporan tersebut sekitar $40 \mathrm{Ha}$ lahan yang telah ditanami tanaman reboisasi telah dirusak, dicabuti dan diganti dengan tanaman perkebunan dan palawija sehingga menimbulkan kerugian negara berkisar Rp. 83.000.000. (Hasibe, 2018)

Sebanyak 11 orang kemudian diseret ke jalur hukum untuk menjalankan proses persidangan atas tuduhan tersebut. Mereka adalah masyarakat yang notabene bekerja sebagai petani dan semuanya berasal dari Dusun Bolalangiri Desa Bonto Kaktute. Rata-rata mereka telah berumur di atas 30 tahun dan telah tinggal sejak lama di wilayah tersebut.

Pada tanggal 03 Juni 2009, para terdakwa diajukan ke persidangan oleh Jaksa Penuntut Umum dengan dakwaan bahwa mereka telah bertempat di Kawasan Hutan Lindung Apparang I Dusun Bolalangiri Desa Bonto Katute Kecamatan Sinjai Borong Kabupaten Sinjai yang telah ditetapkan berdasarkan SK Menteri Pertanian RI dengan Nomor : 760/KPTS/LM/10/1982 tertanggal 12 Oktober 1982. Para terdakwa dituduh melakukan atau turut serta melakukan, mengerjakan, menggunakan dan menduduki kawasan hutan secara tidak sah serta merambah kawasan hutan.

Pada tahap pelaksanaan putusan tersebut, pihak terdakwa pernah memenuhi surat panggilan dari pihak kepolisian. Sehingga para terdakwa tidak pernah menjalani putusan Pengadilan Negeri Sinjai. Selain itu pihak kepolisian tidak pernah menindak lanjuti surat panggilan para terdakwa. Para terdakwa kembali menjalankan aktivitas sehari-hari sekalipun mereka masih cemas apabila sewaktu-waktu kejadian tersebut kembali berulang.

\section{c. Eksplorasi Tambang}

Belum selesai kasus perambahan hutan yang melibatkan masyarakat Dusun Bolalangiri Desa Bonto Katute dengan Dinas Kehutanan Kabupaten Sinjai, kini muncul isu baru yaitu adanya izin eksplorasi tambang di wilayah Desa Bonto Katute. Izin eksplorasi tambang sebenarnya sudah ada sejak tahun 2008, namun hal itu belum diketahui masyarakat setempat. Perusahaan yang menjadi pemegang izin eksplorasi pada saat itu adalah perusahaan milik PT. Galena Sumber Energi. Izin eksplorasi tambang di Desa Bonto Katute itu kemudian diperpanjang berdasarkan hasil evaluasi kegiatan Izin Usaha Pertambangan (IUP) dinyatakan memenuhi syarat untuk diberikan persetujuan perpanjangan IUP eksplorasi. Perpanjangan izin tersebut kemudian tertuang dalam Keputusan Bupati Sinjai No. 402 Tahun 2010 Tentang Persetujuan Perpanjangan Izin Usaha Pertambangan Eksplorasi Kepada PT. Galena Sumber Energi.

Lokasi penambangan yang berada di Desa Bonto Katute memiliki luas 24.830 Ha. Berdasarkan hasil penyelidikan sebelumnya bahwa komoditas utama yaitu mineral logam jenis timah hitam, dan hanya terdapat sedikit emas. Padahal selama ini isu yang berkembang bahwa di Desa Bonto Katute terdapat banyak emas.

Pemberian izin perpanjangan eksplorasi tambang kepada PT. Galena Sumber Energi dimulai pada tanggal 15 November 2010 (SK Bupati Sinjai No. 402 Tahun 2010, 2010). Namun dalam tahap pelaksanaan kegiatan eksplorasi tambang menuai aksi protes dari beberapa masyarakat setempat. Bukan hanya itu beberapa LSM dan organisasi-organisasi mahasiswa yang terdapat di Kabupaten Sinjai maupun di luar Kabupaten Sinjai turut terlibat membantu masyarakat untuk melakukan penolakan terhadap adanya eksplorasi tambang. Dikarenakan 
keberadaan eksplorasi tambang dinilai sangat merugikan bagi masyarakat karena mereka menganggap apabila hal ini dibiarkan maka akan berdampak buruk terhadap kehidupan masyarakat ke depannya.

Guna menunjang aksi penolakan, maka dibentuk posko penolakan di Desa Bonto Katute dan membentuk wadah persatuan masyarakat dan mahasiswa serta LSM yang menolak tambang di Desa Bonto Katute yang dikenal dengan nama Gerakan Rakyat Tolak Tambang Bonto Katute (GERTAK). Untuk menindak lanjuti izin tersebut dilakukan berbagai bentuk penolakan. Adapun bentuk penolakan yang dilakukan melalui jalur diplomasi hingga aksi demonstrasi.

Pada tanggal 11 Januari 2012 GERTAK di Sinjai mengadakan konsolidasi untuk melakukan persiapan aksi pada tanggal 12 Januari 2012 dengan membawa isu tolak tambang Bonto Katute. Pada tanggal 12 Januari 2012 GERTAK melakukan aksi kampanye penolakan tambang Desa Bonto Katute terhadap beberapa pihak yang bersangkutan (DPRD, Pertanahan, Kehutanan dan KAPEDALTAM). Aksi penolakan tersebut dilakukan dengan turun ke jalan bersama dengan beberapa elemen organisasi. (Mapala PTM Lestari, t.thn.)

Selanjutnya GERTAK melaku-kan aksi kampanye penolakan eksplorasi tambang pada tanggal 6 Februari 2012. Aksi tersebut didukung oleh beberapa organisasi daerah yang akan merasakan dampak secara langsung apabila terjadi eksploitasi tambang di Desa Bonto Katute. Organisasi tersebut adalah STAPAL Indonesia yang merupakan organisasi pencinta alam di Kecamatan Sinjai Tengah dan Komunitas Anak Kreatif (KONAK) yang berasal dari para pemuda Kecamatan Sinjai Selatan yang mengandalkan air dari sungai yang berhulu di Bonto Katute sebagai sumber pengairan sawah. Aksi ini bertujuan untuk membagikan selebaran isu kampanye dan menyampaikan aspirasi di Kantor DPRD Kabupaten Sinjai serta mendesak diadakannya dialog terbuka dengan melibatkan semua pihak yang terkait. Hasilnya berbuah kesepakatan bahwa DPRD menerima dan akan segera menindak lanjuti aspirasi para demonstran.

Pada tanggal 13 Februari 2012 kembali terdapat aksi bersama masyarakat dalam bentuk penolakan perencanaan eksplorasi tambang di Desa Bonto Katute. Masyarakat yang bergabung bersama GERTAK menuju kantor DPRD untuk melaksanakan dialog terbuka. Namun, dialog tersebut gagal terlaksana disebabkan DPRD melakukan rapat secara tertutup dan hanya perwakilan yang diperbolehkan masuk. Hal ini memicu bentrok dari para demonstran karena menilai pihak DPRD melanggar hasil kesepakatan sebelumnya mengenai pelaksanaan dialog terbuka. Selanjutnya DPRD membuat kesepakatan akan berkunjung ke lokasi untuk melihat kondisi yang terjadi dan mengadakan dialog bersama masyarakat setempat. Hasil dari dialog inilah tercapai kesepakatan bahwa warga tetap menolak eksplorasi tambang dan mereka diizinkan kembali mengelola lahan mereka asalkan tidak merusak kawasan. (Mapala PTM Lestari, t.thn.)

Semenjak saat itulah suasana konflik mulai mereda, masyarakat tidak lagi terancam dengan adanya pertambangan di wilayah mereka. Selain itu, masyarakat bisa kembali mengelola lahan mereka selama ini yang selama beberapa tahun terakhir menjadi sengketa dengan pihak kehutanan. Namun mereka sepenuhnya belum bisa bebas mengelola tanah atau lahan tersebut karena belum ada bukti kepemilikan yang sah menurut hukum dalam hal ini yang dimaksud sertifikat kepemilikan.

\section{Dampak Konflik \\ a. Dampak Ekonomi}

Konflik Kawasan Hutan Adat Barambang Katute yang menimbulkan dampak terhadap perekonomian masyarakat setempat. Lahan yang digarap secara turun temurun oleh masyarakat dimasukkan dalam wilayah kawasan. Masyarakat yang mayoritas bekerja sebagai petani harus kehilangan lahan dan 
pekerjaan. Sehingga banyak dari mereka yang menjadi buruh bangunan dan harus keluar dari kampung untuk mencari pekerjaan lain. (Rudi, 2018)

Rentang waktu yang cukup panjang mengharuskan masyarakat yang lahannya menjadi tanah sengketa tidak bisa mengelola dan mengambil hasil kebun mereka. Sehingga menyebabkan pendapatan mereka harus mengalami penurunan karena hasil dari kebun tidak ada lagi semenjak pihak kehutanan melarang masyarakat mengelola lahan mereka yang dimasukkan dalam wilayah kawasan. Masyarakat yang pernah dilaporkan oleh pihak kehutanan juga harus menanggung kerugian untuk mengurus biaya pengadilan. (Masri, 2018)

Konflik yang telah berlangsung cukup lama akhirnya bisa mereda setelah mendapatkan kesepakatan antara masyarakat yang menolak dengan pihak pemerintah terhadap penolakan adanya eksplorasi tambang di wilayah Bonto Katute. Setelah adanya pergantian bupati yakni Sabirin Yahya menggantikan Andi Rudianto Asapa riuk isu-isu terkait pengambilalihan lahan oleh negara sudah jarang terdengar lagi. Bahkan masyarakat sudah mulai bebas mengelola lahan mereka sekalipun status tanah yang mereka kelola masih berstatus wilayah kawasan. Pemerintah setempat memperbolehkan mereka menanami lahan mereka dan mengambil hasilnya asalkan mereka tidak merusak wilayah kawasan. (Masri, 2018)

\section{b. Dampak Sosial Budaya}

Setelah melewati rentang waktu yang cukup lama, peristiwa ini telah menorehkan berbagai penderitaan di kehidupan masyarakat. Berdasarkan data yang telah didapat di lapangan bahwa selama terjadinya peristiwa penolakan terhadap daerah kawasan hutan lindung hingga masuknya eksplorasi tambang menyebabkan banyak masyarakat yang menjadi korban intimidasi dan kekerasan dari oknum-oknum polisi kehutanan dan perangkat lainnya. Bahkan tercatat 11 orang masyarakat pada kasus tuduhan perambahan hutan mendapatkan hukuman penjara walaupun sampai saat ini hukuman tersebut tidak terlaksana. Hal ini membuat masyarakat trauma dan menderita tekanan psikis sehingga takut melakukan aktivitasnya sehari-hari sebagaimana mestinya.

Hubungan antara masyarakat yang menolak dan pemerintah setempat juga menyebabkan degradasi sosial sehingga memicu kesenjangan sosial yang berlaku pada sistem pemerintahan tersebut. Masyarakat yang dianggap melawan atau menentang segala kebijakan pemerintah setempat semakin di intervensi dan di intimidasi. Rumah-rumah mereka di kepung dan dilempari batu, guru di mesjid yang juga menolak tambang di berhentikan, pemberian Raskin hanya diberikan pada warga yang tidak menolak tambang bahkan surat nikah bagi warga yang menolak tidak ingin ditanda tangani kepala desa dan banyak tindakan intimidasi lainnya. (Mapala PTM Lestari, t.thn.)

Pasca peristiwa tersebut eksistensi Masyarakat Adat Barambang Katute kini mulai di perjuangkan kembali. Sekalipun masih banyak pihak yang tidak menyepakati dan menilai pemerintah Desa Barambang melakukan secara sepihak namun hal tersebut akhirnya membuahkan hasil. Pada tanggal 28 Desember 2017 Pemerintah Kabupaten Sinjai meresmikan rumah adat Barambang Katute dengan tujuan dapat menunjang pelaksanaan kegiatan adat.

\section{E. Kesimpulan}

Latar belakang terjadinya konflik Kawasan Hutan Barambang Katute yakni disebabkan oleh adanya penetapan wilayah Kawasan Hutan Lindung Apparang pada tahun 1982 tanpa sepengetahuan masyarakat. Penetapan tersebut menjadi dasar dilaksanakannya pengukuran pada tahun 1994 untuk memisahkan wilayah kelola masyarakat dengan wilayah kawasan hutan lindung. Hal ini menimbulkan konflik antara masyarakat setempat dengan pemerintah, masyarakat menganggap bahwa 
lahan mereka yang ditetapkan sebagai wilayah kawasan telah diperoleh secara turun temurun dan juga terdapat hutan larangan (hutan adat) yang telah dijaga secara turun temurun sebagai warisan dari leluhur Masyarakat Adat Barambang Katute.

Dinamika konflik Kawasan Hutan Barambang Katute bermula sejak dilakukannya pengukuran pada tahun 1994 untuk menentukan batas wilayah kelola masyarakat dengan wilayah kawasan hutan lindung. Pengukuran tersebut menuai aksi protes dari masyarakat karena dinilai tidak ada sosialisasi sebelumnya. Pada tahun 1995 terdapat 2 warga yakni Ismail dan Rustam Hamka yang ditahan selama 2 bulan dengan tuduhan menghasut, dan memfitnah kekuasaan umum serta penipuan. Selanjutnya pada tahun 2005 Disbunhut menerapkan program GN-RHL di kawasan hutan lindung di Bonto Katute, tahun 2006-2007 kegiatan pembibitan dan penanaman masih berlangsung lancar hingga pada awal tahun 2008, sebanyak 11 orang Bolalangiri Desa Bonto Katute dilaporkan oleh Disbunhut dengan tuduhan merambah dan merusak kawasan hutan lindung (Hutan Apparang). Mereka menolak tuduhan tersebut dengan alasan lahan tersebut telah dikelola secara turun temurun. Sehingga terjadi sengketa lahan oleh pihak kehutanan dan kasus tersebut diselesaikan lewat jalur hukum. Selanjutnya pada tahun 2010 dikeluarkan izin perpanjangan eksplorasi tambang kepada PT. Galena Sumber Energi di Desa Bonto Katute. Masyarakat kembali melakukan aksi perlawanan dengan dibantu oleh beberapa LSM dan organisasi mahasiswa. Aksi tersebut merupakan puncak dari perlawanan masyarakat terhadap pemerintah daerah terkait masalah sengketa lahan yang terjadi diwilayah mereka. Alhasil diperoleh kesepakatan dengan DPRD Kabupaten Sinjai bahwa masyarakat tetap menolak eksplorasi tambang tersebut.

Dampak yang dirasakan oleh masyarakat setempat adalah dari segi ekonomi beberapa masyarakat kehilangan tanah, pekerjaan, dan mata pencahariannya. Sedangkan dari segi sosial masyarakat menderita tekanan psikis, trauma, terjadi degradasi sosial serta masyarakat yang menolak mendapatkan intervensi dan intimidasi dari pemerintah setempat dan polisi hutan. Dari segi kebudayaan, Setelah konflik itu berakhir masyarakat kembali memperjuangkan keberadaan Masyarakat Adat Barambang Katute sekalipun kedua desa bekas tanah adat tersebut tidak sejalan lagi.

\section{DAFTAR PUSTAKA}

AMAN Sinjai, t.thn. Naskah Akademik Peraturan Daerah tentang Pengakuan dan Pelindungan Hak-hak Masyarakat Adat di Kabupaten Sinjai, s.l.: s.n.

Balai Pemantapan Kawasan Hutan Wilayah VII Makassar, t.thn. s.l., s.n.

BPS , 2006. Kabupaten Sinjai Dalam Angka 2005/2006. Sinjai: Badan Pusat Statistik.

Haryono, 1995. Mempelajari Sejarah Secara Efektif.. Malang: Pustaka Jaya.

Hasan, A., 2018. [Wawancara] 2018.

Hasibe, 2018. [Wawancara] 2018.

Ismail, 2018. [Wawancara] 2018.

Kantor Desa Bonto Katute, t.thn. Inventaris Sejarah Bonto Katute, s.l.: s.n.

Mapala PTM Lestari, t.thn. Kronologi Konflik Bonto Katute. [Online] Available at: mapalaptmlestari.blogspot.com [Diakses 15 November 2018 ].

Mappa, 2018. [Wawancara] 2018.

Masri, M., 2018. [Wawancara] 2018.

Pengadilan Negeri Sinjai Kelas II, t.thn. Inventaris Putusan Pidana Muhase $d k k$, s.l.: s.n.

Priyadi, S., 2012. Metode Penelitian Pendidikan Sejarah. yogyakarta: ombak.

Rahmadi, T., 2015. Hukum Lingkungan di Indonesia. Jakarta: Raja Grafindo Persada.

Rudi, 2018. [Wawancara] 2018. 
SK Bupati Sinjai No. 402 Tahun 2010, 2010. Persetujuan Perpanjangan Izin Usaha Eksplorasi Kepada PT. Galena SUmber Energi. s.l., s.n.

Undang-undang RI No. 41 Tahun 1999 , t.thn. Kehutanan. s.l., s.n. 